Харицька С. В., Колісниченко А. В. Дослідження функціонування професіоналізмів і лінгвістичних технік інкорпорації фахової мови в текстову структуру словника / С. В. Харицька, А. В. Колісниченко // Актуальні питання гуманітарних наук. - Випуск 30. - Дрогобич, 2020. - С. 144-151.

УДК 81’373.46:629.73(045)

\title{
ДОСЛІДЖЕННЯ ФУНКЦІОНУВАННЯ ПРОФЕСІОНАЛІЗМІВ I ЛІНГВІСТИЧНИХ ТЕХНІК ІНКОРПОРАЦІЇ ФАХОВОЇ МОВИ В ТЕКСТОВУ СТРУКТУРУ СЛОВНИКА
}

ХАРИЦЬКА Світлана Василівна orcid.org/0000-0002-9404-9731 кандидат педагогічних наук, доцент кафедри іноземних мов і прикладної лінгвістики Національного авіаційного університету м. Київ (Україна) Skharytskaya@gmail.com

КОЛІСНИЧЕНКО Анна Віталіївна, orcid.org/0000-0002-9596-3103 кандидат філологічних наук, доцент кафедри іноземних мов і прикладної лінгвістики Національного авіаціийного університету м. Київ (Україна)

Safronovaannar@gmail.com

Мета. Метою статті $є$ дослідження професійної лексики представників авіаційної галузі на матеріалі словників і фільмів; визначення статусу і місця ії в системі національної української мови; 
3'ясування значень професійних назв предметів та явищ, вилучених з усної розмовної мови представників авіаційної галузі часів Великої Вітчизняної війни та другої половини $\mathrm{XX}$ століття, а також сучасних авіапрофесіоналізмів; уточнення схожостей та відмінностей професіоналізмів із термінологічними лексичними одиницями, що обслуговують авіаційну галузь; довести, що професійна лексика, будучи неодмінним атрибутом неофіційного професійного спілкування, володіє специфічними характеристиками, що дозволяють виділяти іï в самостійну структуру національної мовної системи.

Методи. Три концепції, які стали підгрунтям у нашому дослідженні фахових мов: системно-лінгвістична, прагма-лінгвістична, когнітивнолінгвістична. Системно-лінгвістична розглядає фахову мову як систему мовних знаків, які використовуються в межах фахової комунікації. Прагма-лінгвістична спрямована на фаховий текст, його контекстуальні зв'язки. Когнітивно-лінгвістична спирається на інтелектуальні та емоційні умови продуцента та реципієнта при вживанні спеціальних мовних знаків у фахових текстах. Виходячи з вищесказаного у нашому дослідженні ми використовували усі три концепції, але, беручи до уваги художні твори, 3 якими ми працювали, перевагу отримала когнітивно-лінгвістична концепція, оскільки саме вона дала змогу правильно оцінити лексичні одиниці (професіоналізми) художніх фільмів.

Результати. Здійснений комплексний аналіз мовного матеріалу, який збирався на основі перегляду художніх фільмів про авіацію «B бой идут одни «старики» («У бій ідуть лише «старі») Леоніда Бикова, «Екіпаж» Олександра Мітти, «Міміно» Георгія Данелії. А також лексичних професіоналізмів, якими послуговуються представники льотного складу Спеціального авіаційного загону оперативно-рятувальної служби цивільного захисту ДСНС України.

Висновки. Детальний аналіз професійної лексики авіаційної галузі шляхом перегляду художніх фільмів середини та кінця XX століття у 
порівнянні із сучасними професіоналізмами дав змогу структурувати дані лексичні одиниці; указати на їх функції у мовленні; визначити семантичні зв'язки як з офіційними термінами, так і з загальновживаною лексикою; виокремити професіоналізми до професійного дискурсу.

Ключові слова: фахова мова, професіоналізм, лексична одиниця, авіапрофесіоналізм, термін, художній фільм.

\title{
RESEARCH OF PROFESSIONALISMS FUNCTIONING AND \\ LINGUISTIC TECHNIQUES OF INCORPORATION OF A PROFESSIONAL LANGUAGE IN THE TEXT STRUCTURE OF THE DICTIONARY
}

\begin{abstract}
Kharytska Svitlana Vasylivna,
Candidate of Pedagogical Sciences, Associate Professor of Department of Foreign Languages and Applied Linguistics

National Aviation University

Skharytskaya@gmail.com orcid.org/0000-0002-9404-9731

Kolisnychenko Anna Vitaliivna,

Candidate of Philological Sciences, Associate Professor of Department of Foreign Languages and Applied Linguistics National Aviation University Safronovaannar@gmail.com orcid.org/0000-0002-9596-3103
\end{abstract}

Purpose. The purpose of the article is to study the professional vocabulary of the aviation industry on the basis of dictionaries and films; to determine its status and place in the system of the national Ukrainian language; to clarify the meanings of professional names of objects and phenomena removed from the oral colloquial language of the aviation industry during the 
Great Patriotic War and the second half of the twentieth century, as well as modern aviation professionalisms; to clarify the similarities and differences between professionalisms and terminological lexical units that serve the aviation industry; to prove that professional vocabulary, being an indispensable attribute of informal professional communication, has specific characteristics that allow to distinguish it into an independent structure of the national language system.

Methods. Three concepts that became the basis in our study of professional languages: system-linguistic, pragma-linguistic, cognitivelinguistic. System-linguistic considers professional language as a system of linguistic signs used in professional communication. Pragma-linguistics focuses on the professional text, its contextual connections. Cognitive-linguistic is based on the intellectual and emotional conditions of the producer and recipient in the use of special language signs in professional texts. Based on the above, in our study we used all three concepts, but, taking into account the works of art from which we studied, the cognitive-linguistic concept prevailed, because it allowed assessing the lexical units (professionalism) of feature films correctly.

Results. A comprehensive analysis of the language material, which was collected on the basis of watching feature films about aviation "Only "old men" go into the battle" by Leonid Bykov, "Crew" by Oleksandr Mitta, "Mimino" by Georgy Danelia. And also lexical professionalisms which are used by representatives of flight structure of Special aviation group of operative-rescue service of civil protection of the State service of Ukraine on emergency situations.

Conclusions. A detailed analysis of the professional vocabulary of the aviation industry by watching feature films of the middle and end of the twentieth century in comparison with modern professionalism made it possible to structure these lexical units; indicate their functions in speech; identify semantic connections with both official terms and common vocabulary; to single out professionalisms to professional discourse. 
Key words: professional language, professionalism, lexical unit, aviation professionalism, term, feature film.

\section{1. Ветуп}

Фахова мова - спеціальна мова, що обслуговує конкретну сферу чи галузь знань. Термін «фахова мова» у сучасній лінгвістиці набув широкого вживання в 60-70 роки XX століття в німецькомовних країнах, де його використовували зі значенням «мова певної галузі, фаху». Однак, окремі уявлення та перші роботи, що відображали різні сторони та властивості цього явища, стали з'являтися в зарубіжній лінгвістиці ще в кінці XIX - на початку XX століття. Уперше термін «фахова мова» було вжито представниками Празького лінгвістичного гуртка. Основна його ідея трактування мови як функціональної системи засобів вираження, яка служить певній меті. Вони стояли на засадах функціонального підходу щодо лінгвістичного аналізу мовних систем (Google 2017). Широкого розповсюдження набула теза про те, що найголовнішою рисою мовних систем $є$ їхнє функціональне призначення, практичне застосування, тобто мова має цілеспрямований характер (Вискушенко, 2015)

Аналіз значної кількості робіт вітчизняних та зарубіжних мовознавців за останні роки виявив, що серед дослідників немає єдності у трактуванні поняття фахової мови. Відсутня і загальноприйнята дефініція даного терміна. У британській та американській лінгвістиці для позначення фахово-маркованої лексики використовують термін «language for special/specific purposes» (LSP) - «мова для спеціальних цілей», який увійшов у вжиток наприкінці XX століття. У системі фахових мов можна виділяти безкінечні підвиди фахової мови, наприклад: медична, економічна, юридична, мова реклами, спорту, IT технологій, будівельна, авіаційна і т. д. Із виникненням нових галузей науки та знань із бурхливим розвитком технологій, виникає потреба створення спеціальної лексики та термінологічних систем, що і стають основою формування та зародження нових фахових мов (професіоналізмів). Наразі відомі три концепції, які 
стали підгрунтям у дослідженні фахових мов: системно-лінгвістична, прагма-лінгвістична, когнітивно-лінгвістична. Системно-лінгвістична розглядає фахову мову як систему мовних знаків, які використовуються в межах фахової комунікації. Прагма-лінгвістична спрямована на фаховий текст, його контекстуальні зв'язки. В такому разі фахова мова є не тільки системою знаків, що забезпечують фахову комунікацію, але й текстовими висловлюваннями, за допомогою яких вона відбувається. Когнітивнолінгвістична спирається на інтелектуальні та емоційні умови продуцента та реципієнта при вживанні спеціальних мовних знаків у фахових текстах (Roelcke, 2005). Виходячи з вищесказаного у нашому дослідженні ми послугувалися когнітивно-лінгвістичною концепцією, оскільки саме вона дає змогу правильно оцінити функціонування лексичних одиниць (професіоналізмів) у площині художніх фільмів.

Мета. Метою статті $\epsilon$ дослідження професійної лексики представників авіаційної галузі на матеріалі словників i фільмів, визначення статусу і місця її в системі національної української мови; 3’ясування значень професійних назв предметів та явищ, вилучених з усної розмовної мови представників авіаційної галузі часів Великої Вітчизняної війни та другої половини $\mathrm{XX}$ століття, a також сучасних авіапрофесіоналізмів; уточнення схожостей та відмінностей професіоналізмів 3 термінологічними лексичними одиницями, що обслуговують авіаційну галузь; акцентування, що професійна лексика, будучи неодмінним атрибутом неофіційного професійного спілкування, володіє специфічними характеристиками, що дозволяють виділяти їі в самостійну структуру національної мовної системи.

\section{2. Теоретичне обгрунтування терміну «фахова мова»}

Чимала кількість визначень терміна «фахова мова» різними лінгвістами зумовлюється тим, які аспекти: комунікативно-функціональні, соціологічні, прагматичні чи текстуальні взято за основу кожного 3 цих трактувань. У своєму визначенні фахової мови К.-Р.Редікер обмежується 
фаховою комунікацією в письмовій та усній формі між спеціалістами окремих сфер професійної діяльності, які обмінюються особливим станом справ. (Redicker, 1998) Хоча він і не відкидає загальновживану лексику. Р.Байєр під фаховою мовою розуміє більше, ніж лексичні зміни мовної системи, а саме комплексну сферу мовного використання, яка виявляє внутрішній розподіл, зумовлений специфікою різних фахових ситуацій. Фахова мова включає сукупність загальновживаних мовних засобів та виявляє характерні риси на лексичному, морфологічному та синтаксичному рівнях. Мова виникла як результат необхідності передачі інформації, тобто спілкування. У соціально-психологічному плані спілкування - це обмін інформацією, вчинками, думками, переживаннями, це процес виховання та самовиховання, це форма творчості, яка допомагає виявляти i розвивати кращі сторони особистості. Іншими словами, спілкування - це сукупність зв'язків і взаємодія індивідів, груп, спільнот, під час яких відбувається обмін інформацією, досвідом, уміннями, навичками і результатами діяльності (Леонтьєв, 1974).

Спілкування - це невід'ємна умова діяльності людини. Правильно організоване спілкування забезпечує ефективний обмін інформацією, дає змогу глибше пізнати співрозмовника, спрогнозувати особливості подальшої ділової взаємодії з партнером. Отже, спілкування виконує такі функції як: комунікація, взаємодія, сприймання та розуміння. Для ефективного професійного спілкування важливо, щоб воно відбувалося на всіх виділених Андрєєвою Г. М. рівнях: комунікативному - обмін інформацією; інтерактивному - обмін не лише інформацією та знаннями, а й діями; перцептивному - не тільки сприйняття учасниками комунікації один одного, а й досягнення взаєморозуміння. (Андрєєва, 1980)

Найзмістовнішим та найвиразнішим засобом впливу на учасників спілкування є мова. Мова проявляється через живий процес, що називається мовленням. Мовлення виникає у процесі спілкування, яке відбувається в певному колі (професійно-ділому чи родинно-дружньому), 
певних часових межах, матеріалізуючись у звуках, інтонації, жестах i міміці, або буквах і розділових знаках (при вираженні своїх думок на письмі). Як ми зазначали вище, основним завданням мовлення під час спілкування є досягнення взаєморозуміння.(Натанзон, 1972).

К.-Р.Редікер розмежовує загальновживану та фахову лексику, вказуючи на те, що остання частіше підлягає суворій логіці (Redicker, 1998). Р.Байєр, навпаки, під фаховою мовою розуміє більше ніж лексичні зміни мовної системи, а саме комплексну сферу мовного використання, яка виявляє внутрішнє диференціювання, зумовлене специфікою різних фахових ситуацій. Фахова мова включає сукупність загальновживаних мовних засобів та виявляє характерні риси на лексичному, морфологічному та синтаксичному рівнях (Beier, 1980).

Однак, «мова для спеціальних цілей», що обслуговує наукововиробничу сферу людських відносин, складається не тільки 3 термінів. Вони не обов'язково повинні мати логічні визначення, вона можуть характеризуватися наочно або малюнком. Для позначення деяких предметів використовуються не тільки слова і словосполучення, а й буквенно-числова індексація: «Ауді - 600», «3АЗ - 968М», «Ан - 26» та інші.

Із середини минулого століття науковці почали ретельно підходити до укладання словників, які почали включати фахові лексичні одиниці, звертаючи увагу на важливість залучення фахових спеціалістів до їх творення. 1961 рік був названий роком відкриття нової галузі мовознавства - термінознавства. Протягом наступний десятиліть наука активно розвивається, ведуться грунтовні дослідження, з’являються роботи молодих учених С.В.Гринева, В.П.Даниленка, Т.Л.Канделаки, Д.С.Лотте та інших, які змінюють уявлення про науку як ізольовану одиницю і все більше розглядають термінознавство як комплекс взаємопов'язаних дисциплін (Гринев, 2004). 3' являються різні напрямки дослідження такі як: загальне, методологічне, філологічне, порівняльне, історичне, 
функціонально-стилістичне, гносеологічне i деякі інші. Інтенсивний прогрес науки, поглиблюючи людські знання про будову світу, про наукові об'єкти, змінюючи історичну форму і стиль наукового мислення, привів до появи ще однієї нової науки когнітології, яка грунтується на філософському вивченні наукового пізнання i когнітивної психології. Розглядаючи процеси пізнання і мислення, вона не може не зачіпати проблеми мови i мислення, адже в процесі пізнання «з'являється взаємозв'язок сенсорної та мисленнєвої діяльності індивіда», що переростає в «керування діями» (Гамезо, 2006), у осмислене мовне вираження ідей. Традиційне вивчення мови не задовольняє науковий інтерес лінгвістів, і антропологічний аспект виходить на перший план в наукових дослідженнях. У кінці 80 -х років XX ст. сформувався новий напрям дослідження мови - когнітивна лінгвістика, що вивчає мову у взаємозв'язку з людиною, з її свідомістю, мисленням, діяльністю. До числа актуальних проблем, що привертають увагу лінгвістів сьогодення, по праву можна віднести людський фактор у використанні мови.

\section{3. Професіоналізми (вузькофахова лексика), їх особливості}

Слово як термін знаходиться в системі понять, які складають «понятійний запас» (Суперанская та інші, 1989). Слово як номен (слово як позначення предмета) входить не в понятійну систему, а в предметнотематичну групу лексики тієї чи іншої виробничої або технічної галузі. Окрім номенклатурних найменувань в «мові для спеціальних цілей» виділяють ще й професіоналізми (вузькофахову лексику). Але усі ці одиниці пов'язані у мовленні загальновживаними мовними одиницями, які характеризуються неофіційністю і мають розмовний характер. Професійна лексика являє собою величезний прошарок мовних одиниць активного використання. Так, наприклад, мова українського педагога збагатилася запозиченнями такими як: тьютор - (від англ. tutor - учитель) - особа, що веде індивідуальні або групові заняття із учнями, студентами, репетитор, наставник, коуч (англ. coach) - фахівець, тренер, що проводить тренування, 
модератор - людина, що відповідає за дотриманням встановлених норм поводження на інтернет-ресурсах, частіше форумах (що стало надзвичайно актуальним під час пандемії Covid-19), це наставник i керівник, який здійснює і організацію активної роботи групи; з'явилися абревіатури, зрозумілі педагогічному колу спеціалістів: СОТ - сучасні освітні технології, СДУГ (Синдром дефіциту уважності та гіперактивності) - це порушення розвитку нервової системи, РАС (Розлади аутичного спектра) порушення психічного розвитку, що характеризується вираженим дефіцитом соціальної взаємодії, здатності до спілкування та пізнання довкілля, втратою інтересу до реальності, MOOC (від англ. Massive open online course) - масові відкриті онлайн-курси; види навчання: адаптивне, інклюзивне та багато іншого. Але усі ці лексичні одиниці містяться у різного типу словниках i досить добре описані 3 грунтовними поясненнями.

Наведемо приклади фахової лексики 3 іншої галузі людської діяльності - авіації. Вказана сфера діяльності не є доступною і зрозумілою кожному, але почувши, чи прочитавши якийсь термін ми можемо відшукати його значення як у тлумачному словнику загальновживаної лексики так і у фаховому тлумачному словнику. Наприклад, фюзеляж - це корпус літака, вертольота, планера, який служить для поєднання всіх їх частин та для розміщення екіпажу, пасажирів, вантажів (Словник, 1979), в той самий час існує паралельно слово-професіоналізм із тим самим значенням - «бочка», що у словнику не зазначено; шасі - висувний або нерухомий пристрій 3 колесами, лижами або поплавцями для зльоту i посадки літака, а також для переміщення його по аеродрому, палубі авіаносця або воді (Словник, 1979), автопілот - пристрій для автоматичного керування літаком (Словник, 1979).

На відміну від термінів, які описані і пояснені у фахових словниках, існують професіоналізми, вони мало вивчені, що пов'язано з труднощами збору матеріалу: ці мовні одиниці характерні для усного мовлення та рідко 
зустрічаються в письмових джерелах, хоча у вузьких колах $є$ добре зрозумілими. Факт виникнення та існування прошарку неофіційної виробничо-професійної лексики пояснити 3 точки зору сучасного мовознавства досить важко. Здавалося б, терміни в своєму прагненні дати всебічну характеристику об'єкту науково-виробничої дійсності покривають всі потреби номінації. Однак неофіційні професійні назви активно існують паралельно термінам.

Професіоналізми - це напівофіційні стилістично марковані мовні одиниці (слова або словосполучення), уживані у професійному мовленні вузьким колом фахівців на позначення відомого поняття. Оскільки професіоналізми вживають на позначення певних понять лише у сфері тієї чи іншої професії, ремесла, промислу, вони не завжди відповідають нормам літературної мови і можуть бути не зрозумілими пересічній особі. Професіоналізми є неофіційними синонімами до термінів, вони досить різноманітні щодо семантичних характеристик, виникають стихійно на власній мовній основі, завдяки своїй точності і влучності приживаються і витісняють відповідні офіційні терміни. Галузеві ж терміни переважно творяться свідомо, часто 3 використанням чужомовних слів та словотворчих засобів. Українські дослідники послідовно висловлюють думку, що терміни потрібно відокремлювати від професіоналізмів. А.С. Д'яков, Т.Р. Кияк, З.Б. Куделько зазначають: «Доцільним є розмежування професіоналізмів і термінів, котрі разом становлять поняття спеціальної субмови» (Д'яков та інші, 2000). Ми хочемо зупинитися i наголосити на тому, що терміни i професіоналізми мають спільні й відмінні риси. Спільним є те, що ці обидві мовні одиниці вживаються в професійній галузі людської діяльності, але останні можуть бути зрозумілими лише у певному контексті або у певному колі спеціалістів. На відмінностях зупинимося докладніше. За Т.В. Михайловою перелік відмінностей професіоналізмів від термінологічних мовних одиниць становить: 1) вони є локально скорочені й спрощені назви, які дублюють 
терміни; 2) терміни є унормованими лексичними одиницями, а професіоналізми - напівофіційними; 3) терміни функціонують як в усному так і в писемному спілкуванні фахівців певної галузі, професіоналізми вживаються лише у розмовному мовленні; 4) професіоналізмам властиві конотації (експресивне забарвлення); 5) терміни функціонують в усіх галузях наукової та виробничої діяльності людини, професіоналізми найчастіше трапляються в окремих професіях; 6) терміни можуть утворюватися засобами національної та чужих мов, професіоналізми лише національної мови; 7) системність - найважливіша ознака термінології, системні зв'язки між професіоналізмами слабші, бо вони називають окремі предмети і видові поняття (Михайлова, 2002).

\section{4. Авіапрофесіоналізми (аналіз фільмів)}

Доречно було б зупинитися на аналізі професіоналізмів, які можна почути у найбільш відомих фільмах про авіацію «B бой идут одни «старики» («У бій ідуть лише «старі») Леоніда Бикова, «Екіпаж» Олександра Мітти, «Міміно» Георгія Данелії.

Військовий художній фільм режисера Леоніда Бикова знятий в УРСР на кіностудії ім. Олександра Довженка з'явився у 1973 році й відразу зайняв перші місця у прокаті. У фільмі розповідається про бойові будні гвардійського полку льотчиків-винищувачів під час Великої Вітчизняної війни, в основі сюжету - життя молодих льотчиків другої «співочої» ескадрильї. Нашу ж увагу привертають лексичні одиниці, що надають живого забарвлення мові у фільмі. Саме таку функцію виконують професіоналізми, які у іншій ситуації не мали б такого ефекту.

Уже у самій назві фільму знайомимося із першим із них - «старики» («старі»). За звичних умов ця лексична одиниця має значення - люди похилого віку із значним життєвим досвідом, але у фільмі «старикам» трохи більше двадцяти i увесь їхній життєвий досвід полягає у майстерності ведення бою. Антонімічним до нього $є$ інша лексична одиниця «жовторотики». У основному своєму значенні жовторотик - це 
молоде, навіть, мале пташеня, яке відрізняється від дорослого птаха жовтим забарвленням навколо дзьоба. Та у фільмі - це молоде поповнення бойових льотчиків, яких називають випуском «зліт-посадка». Інша лексична одиниця, яка постійно зривається із вуст героїв «завалити». Звичайно, що значення у слова зовсім інше, ніж тим, ми розуміємо його за сюжетом. «Завалити» - тут означає підбити, збити ворожий літак. Командир ескадрильї навчає новачків майстерності ведення бою, рекомендуючи «утриматись на хвості» - переслідувати противника не відстаючи від нього. Надзвичайно популярний серед режисерів, які знімали фільми про війну є літак У-2, його другою назвою, яка є також професіоналізмом - це «кукурузник», але вона вже стала впізнаваною i, навіть, не виникає інших асоціацій, та у фільмі герої другої ескадрильї називають його жартома «швейною машинкою». Ще один літак - тепер ворожий, у картині ми часто чуємо «бубнові». Бубни - це червона карточна масть, наймолодша 3 чотирьох. Але, герої-льотчики так називають «месершміти», на фюзеляжах яких були відповідні зображення. Часто військові льотчики-винищувачі, описуючи бій, вживають «бреющ⿻ий nолет» («поземний політ»). Звісно, що ніхто нікого не голив під час польоту - це означає летіти низько над лісом, майже чіпляючи верхівки, часто із вимкнутим двигуном. Ще один професіоналізм, який прийшов до нас саме із авіації «дати добро» або просто «добро»- хороші погодні умови для здійснення польоту. Інша лексична одиниця, яка поєднує непоєднуване «няні-механіки» - так представляють молодих льотчиків їхнім механікам.

Фільм режисера Георгія Данелії «Міміно», 1977 року - це радянський трагікомедійний художній фільм, жанр якого деякі критики визначають як напівказка. Це історія пілота вертольота Мi-2 місцевих авіаліній. Він живе з дідом, незаміжньою сестрою і їі сином-школярем в гірському селі Таркло в околицях невеликого містечка Телаві, куди возить пасажирів і вантажі з усієї округи на вертольоті. Одного разу в аеропорту 
Тбілісі він зустрічає свого колишнього однокурсника, який літає на міжнародних лініях на Ту-144. Звичайно, створюючи фільм про таку цікаву і неординарну професію як льотчик, неможливо не використати професіоналізми для більшої правдивості і реальності існування схожих героїв серед нас. Грузини надзвичайно емоційні і під час одного з рейсів головний герой Валіко Мізандарі (Міміно) називає свій вертоліт «бабочка» («метелик»), значення цього слова зовсім не відповідає літальному апарату, але серед льотчиків воно широковживане поряд із «стрекоза» («бабка») та «вертушка» («дзига»). Серед представників авіаційної галузі також розповсюджені назви літаків «тушка», що стосується лайнерів, розроблених конструкторським бюро Туполева. Наступними професіоналізмами є вже усталені словосполучення «велика авіація» та «мала авіація». Такий поділ є умовним, оскільки знання та навички пілотів мають бути доведеними до найвищого рівня, щоб здійснювати польоти. Міміно працює у «малій авіації», а мріє про «велике» небо.

Про «інше» небо також мріє герой відомого фільму про льотчиків «Екіпаж» Олександра Мітти, 1979 року. Це радянський двосерійний кінороман 3 елементами фільму-катастрофи. Один із головних героїв картини Ненароков Валентин Георгієвич мріє літати у небі для лайнерів. Фільм насичений яскравими професіоналізмами, які іноді викликають усмішку. Так, наприклад, під час судового засідання, дружина льотчика В. Ненарокова Алефтина говорить про свого чоловіка, що той називає день отримання заробітної платні «Днем авіації», а авіаційну емблему у вигляді крил - «курищей» («куркою»). Очевидно, що жодне 3 них не має свого основного значення і зрозуміле лише людям, що мають відношення до професії льотчика. Автопілот у літаку також жартома називають «захист від дурня». Командир корабля після зльоту дає команду слідкувати за погодними умовами, щоб не потрапити у грозовий фронт, бо літак не витримає «болтанки» («хитавиці»). Науковим відповідником цій лексичній одиниці є турбулентність. 
Вивчаючи сучасні професіоналізми льотного складу Спеціального авіаційного загону оперативно-рятувальної служби цивільного захисту ДСНС України, можемо стверджувати, що вони (професіоналізми) дещо змінилися, оновилися, але нікуди не зникли із професійного спілкування.

Майже кожен літак має неформальну назву - номен: Ан-24 - «гидке каченя», Ан-2 - «довгожитель», або дуже ніжно «Аннушка», Ан-32П «пожежник», «водяний бомбардувальник», «кілер вогню» i т.д. «Бетонка» - злітна смуга, укладена бетонними плитами, «рульожка» смуга для буксирування літаків. «Летун» («літун») - пілот, льотчик. Неформальні назви авіамашин з'являються від того, якої якості вони $є$. Так, наприклад: «топор», «гроб», «ворона» («сокира», «труна», «ворона») - це все порівняння для літаків 3 поганими технічними i льотними якостями. «Чорний ящик» - бортовий самописець, пристрій реєстрації. Хоча насправді цей прилад має яскраво помаранчеве забарвлення. Маленькі аеродроми, як правило, називають «карликами».

Можна наводити ще безліч прикладів вживання у професійному спілкуванні слів та словосполучень, які не є термінологічними одиницями даної сфери діяльності, але існують паралельно із ними і вживаються набагато частіше.

Виконуючи важливу номінативно-комунікативну функцію, вони точно називають деталь виробу, ланку технологічного процесу чи певне поняття й у такий спосіб сприяють кращому взаєморозумінню. Частина професіоналізмів переходить до термінів, зазнаючи при цьому структурних змін; деякі з них, не стаючи термінами, усе ж уживаються в науковій мові 3 певними застереженнями (здебільшого їх виділяють лапками, тоді як терміни вживають звичайно без лапок) (Романова, 2013).

\section{5. Висновки}

У даній статті було проведено дослідження професійної лексики. Аналізу піддавалися професійні назви авіагалузі, що відносяться до номінацій середини та кінця XX ст. та початку XXI ст. Спостереження за 
професійною лексикою в різних мовних ситуаціях, аналіз сучасних і діалектних професійних номінацій дозволив виявити характерні особливості, які виділяють об'єкт, що розглядається в окрему підсистему мови - професійний дискурс. Джерелом утворення усіх профессіоналізмів $\epsilon$ різні підсистеми рідної мови. Запозичені слова використовуються в професійній номінації рідко.

Структурний склад професіоналізмів сучасної мови представлений переважно однослівними найменуваннями. Однослівними $\epsilon$ переосмислення загальновживаного слова. Рідше професіоналізми є двочи трикомпонентними найменуваннями. Домінуючою частиною мови в розряді професійної лексики виступає іменник з переважанням категорії конкретності. Прикметники та дієслова представлені незначною кількістю. Професійна лексика - активно бере участь у всіх загальномовних семантичних відносинах, утворюючи різні варіанти: синоніми, полісемію, омоніми, антоніми і всередині однієї професійної системи, і в загальній, міжпрофесійній системі, утворюючи співвідносні семантичні зв'язки і 3 офіційними термінами, і 3 загальновживаною лексикою. Професійна лексика, представляючи сукупність номінацій, забезпечує не тільки оптимальність одномоментного спілкування, а й підтримку виробничих традицій професійно замкнутої групи, що поряд 3 яскраво вираженим соціальним характером професійного номена i наявністю необхідних складових в його мовному оточенні дозволяє говорити про існування власного дискурсу, який поділяється на галузеві субмови, що дає подальші шляхи для дослідження. Широке функціональне вживання професіоналізмів не тільки в умовах професійного дискурсу, а й в різних підсистемах літературної мови свідчить про високий рівень затребуваності даного об'єкту. Основними причинами використання професіоналізмів у текстах літературної мови (сценаріях фільмів) виступають: відсутність офіційного аналога, знайомство з професією при навчанні, а також впливає і естетична функції. 
Отже, говорячи про художні фільми про авіацію, у яких вживання професіоналізмів, які існували у даний період, для більшої наочності та правдивості є досить виправданим і цілком зрозумілим. Було б нецікаво спостерігати за героями фільмів, слухати їхні діалоги якби їхня мова була насичена формальними фаховими одиницями, сухими беземоційними репліками. Задовольняючи вимоги професійної комунікації, мовний компонент реалізує індивідуально-суб'єктивні та універсально-об'єктивні потреби читача/слухача/глядача. Безумовно, можуть зустрічатися помилки у вживанні професіоналізмів, особливо митцями, які створюють художні образи у кіно, що дозволяє давати рекомендації про їх вживання. Слід пам'ятати про неофіційну, ненормовану характеристику даної лексики i про необхідність дозовано і максимально продумано вводити їі в текст літературної мови, підкреслюючи статус, виокремлюючи лапками на письмі та інтонаційно у мовленні. Крім того, професійна лексика - лексика обмеженого вживання рамками однієї конкретної професійної сфери, тому необхідно вводити в текст пояснення значення для неспеціалістів. Але, якщо у художньому творі це можна зробити, то у фільмі практично неможливо - не можна зупинити кадр і пояснити глядачеві про що йдеться, тому саме при написанні сценарію для майбутнього фільму треба бути надзвичайно уважним, щоб не перенасичити лексику героїв незрозумілими одиницями.

Професіоналізми (фахова лексика) вже давно з’явилися у відповідних фахових словниках як синоніми до основних термінів і, навіть, зайняли своє місце у звичайних тлумачних словниках загальновживаної лексики із відповідним позначенням - розм. авіа (ми зупинилися саме на них).

Та все ж, на нашу думку, робота із лексичними одиницями, що отримали назву професіоналізми, проведено недостатньо: словники укладаються та видаються (перевидаються) в Україні не досить часто. Мова як живий організм змінюється, лексичні одиниці, що були 
характерними і зрозумілими в кінці минулого століття можуть втрачати свою актуальність або набирати інших відтінків мови. Доречним було б оновлення фахових словників раз на десятиліття.

Наразі грунтовного дослідження потребує зміна значень професіоналізмів у словниках для заповнення теоретичних лакун лексикосфери фахової мови неофіційного спілкування. Саме на цей аспект варто звернути увагу в контексті наших подальших досліджень.

\section{Список використаних джерел:}

1. Андреева Г.М. Социальная психология. Учебник для высших учебных заведении. - М.: Аспект Пресс, 2001. - с.290.

2. Вискушенко С. А. Фахова мова як об’єкт лінгвістичного дослідження, 2015

https://naub.oa.edu.ua/2015/\%D1\%84\%D0\%B0\%D1\%85\%D0\%BE\%

D0\%B2\%D0\%B0-\%D0\%BC\%D0\%BE\%D0\%B2\%D0\%B0-

$\% \mathrm{D} 1 \% 8 \mathrm{~F} \% \mathrm{D} 0 \% \mathrm{BA}-$

\%D0\%BE\%D0\%B1\%D1\%94\%D0\%BA\%D1\%82-

\%D0\%BB\%D1\%96\%D0\%BD\%D0\%B3\%D0\%B2\%D1\%96\%D1\%81

$\% \mathrm{D} 1 \% 82 \% \mathrm{D} 0 \% \mathrm{~B} 8 \% \mathrm{D} 1 \% 87 \% \mathrm{D} 0 \% \mathrm{BD} \% \mathrm{D} 0 \% \mathrm{BE} \% \mathrm{D} 0 \% \mathrm{~B} 3 \% \mathrm{D} 0 \% \mathrm{BE}$

I

3. Гамезо М. В., Домашенко М. В. Атлас по психологи: Информ.метод. Пособие курсу «Психология человека». 2006. С. 136.

4. Гринев, С.В. Введение в терминоведение [микроформа]. 2004.

5. Д'яков А.С., Кияк Т.Р., Куделько З.Б. Основи термінотворення: Семантичні та соціолінгвістичні аспекти. 2000. С. 15.

6. Леонтьєв А.А., Психологія спілкування. 1974.

7. Михайлова Т. В. Семантичні відношення в українській науковотехнічній термінології. 2002.

8. Натанзон Э. Ш. Приемы педагогического воздействия. 1972.

9. Празький лінгвістичний гурток. 2017. 
https://uk.wikipedia.org/wiki/\%D0\%9F\%D1\%80\%D0\%B0\%D0\%B7 \%D1\%8C\%D0\%BA\%D0\%B8\%D0\%B9 \%D0\%BB\%D1\%96\%D0\% BD\%D0\%B3\%D0\%B2\%D1\%96\%D1\%81\%D1\%82\%D0\%B8\%D1\% 87\%D0\%BD\%D0\%B8\%D0\%B9 \%D0\%B3\%D1\%83\%D1\%80\%D1 $\% 82 \% \mathrm{D} 0 \% \mathrm{BE} \% \mathrm{D} 0 \% \mathrm{BA}$

10. Романова О.О. Спеціальна лексика української мови як об’єкт лінгвістичного дослідження : термін і професіоналізм. Термінологічний вісник. 2013. Вип. 2(1). С. 42-47.

11. Словник української мови. $1970-1980$.

12. Суперанская А.В., Подольская Н.В., Васильева Н.В. Общая терминология. 1989. С. 243.

13. Beier R. Englische Fachsprache. 1980.

14. Redicker C.-H. Wirtschaftsenglisch als Fachsprache und „Entscheidungsorientierte Landeskunde“. 1998.

15. Roelcke T. Fachsprachen. 2005. P. 16-17.

\section{References:}

1. Andreyeva G.M. Sotsial'naya psikhologiya. Uchebnik dlya vysshikh uchebnykh zavedenii. [Social Psychology. Textbook for higher education], 2001 [in Russian].

2. Vyskushenko S. A. Fakhova mova yak ob"yekt linhvistychnoho doslidzhennya, 2015 [in Ukrainian].

https://naub.oa.edu.ua/2015/\%D1\%84\%D0\%B0\%D1\%85\%D0\%BE\%D0 \%B2\%D0\%B0-\%D0\%BC\%D0\%BE\%D0\%B2\%D0\%B0\%D1\%8F\%D0\%BA-\%D0\%BE\%D0\%B1\%D1\%94\%D0\%BA\%D1\%82\%D0\%BB\%D1\%96\%D0\%BD\%D0\%B3\%D0\%B2\%D1\%96\%D1\%81\%D 1\%82\%D0\%B8\%D1\%87\%D0\%BD\%D0\%BE\%D0\%B3\%D0\%BE/

3. Gamezo M. V., Domashenko M. V. Atlas po psikhologi: Inform.-metod. Posobiye kursu «Psikhologiya cheloveka» [Atlas in psychology: Inform.method. The allowance for the course "Human Psychology."], 2006, p. 136 [in Russian]. 
4. Grinev, S.V. Vvedeniye v terminovedeniye [mikroforma] [Introduction to terminology], 2004 [in Russian].

5. D'yakov A.S., Kyyak T.R., Kudel'ko Z.B. Osnovy terminotvorennya: Semantychni ta sotsiolinhvistychni aspekty [Fundamentals of term formation: Semantic and sociolinguistic aspects], 2000, p. 15 [in Ukrainian].

6. Leont'yev A.A., Psykholohiya spilkuvannya,[ Psychology of communication], 1974 [in Ukrainian].

7. Mykhaylova T. V. Semantychni vidnoshennya v ukrayins'kiy naukovotekhnichniy terminolohiyi [Semantic relations in Ukrainian scientific and technical terminology], 2002 [in Ukrainian].

8. Natanzon E. SH. Priyemy pedagogicheskogo vozdeystviya [Receptions of pedagogical impact], 1972 [in Russian].

9. Praz'kyy linhvistychnyy hurtok, 2017 [in Ukrainian]. https://uk.wikipedia.org/wiki/\%D0\%9F\%D1\%80\%D0\%B0\%D0\%B7\%D 1\%8C\%D0\%BA\%D0\%B8\%D0\%B9_\%D0\%BB\%D1\%96\%D0\%BD\%D0 \%B3\%D0\%B2\%D1\%96\%D1\%81\%D1\%82\%D0\%B8\%D1\%87\%D0\%B D\%D0\%B8\%D0\%B9\%D0\%B3\%D1\%83\%D1\%80\%D1\%82\%D0\%BE $\% \mathrm{D} 0 \% \mathrm{BA}$

10. Romanova O.O. Spetsial'na leksyka ukrayins'koyi movy yak ob'yekt linhvistychnoho doslidzhennya: termin i profesionalizm [Special vocabulary of the Ukrainian language as an object of linguistic research: term and professionalism], 2013, Vyp. 2(1), pp. $42-47$ [in Ukrainian].

11. Slovnyk ukrayins'koyi movy: v 11 tt. [Dictionary of the Ukrainian language], 1970—1980 [in Ukrainian].

12. Superanskaya A.V., Podol'skaya N.V., Vasil'yeva N.V. Obshchaya terminologiya.[ General terminology], 1989, p.243 [in Russian].

13. Beier R. Englische Fachsprache [English technical language], Stuttgart, Berlin, Köln, Mainz: Kohlhammer,1980 [in German]. 
14. Redicker C.-H. Wirtschaftsenglisch als Fachsprache und „Entscheidungsorientierte Landeskunde“ [Business English as a technical language and «decision-orientedregional studies»], Hamburg: Rebo-Star, 1998 [in German].

15. Roelcke T. Fachsprachen [Technical language], Berlin: Erich Schmidt Verlag GmbH,2005, pp. 16-17 [in German].

Стаття надійшла в редакцію 16. 06. 2020 р. 